\title{
Hubungan Perilaku Sleep Hygiene Dengan Kualitas Tidur Pada Lansia Di Panti Tresna Werdha Ambon
}

\author{
Fitriyanti Patarru', Rosmina Situngkir, Iriani Bate, Jefvans Evita Akollo \\ Program Studi Ilmu Keperawatan, Sekolah Tinggi Ilmu Kesehatan Stella Maris Makassar
}

\begin{tabular}{l} 
Info Artikel \\
\hline Riwayat Artikel: \\
Received : 18 Oktober 2021 \\
Revised : 26 November 2021 \\
Accepted : 02 Desember 2021 \\
\hline
\end{tabular}

\section{Kata Kunci:}

Sleep Hygiene

Kualitas Tidur

Lansia

\begin{abstract}
ABSTRAK
Latar Belakang: Pada umumnya lansia memiliki waktu tidur berkisar 6-7 jam per hari. Kualitas tidur yang sangat kurang dapat menyebabkan beberapa masalah kesehatan yaitu insomnia. Salah satu faktor yang mempengaruhi yaitu lingkungan yang meliputi, suasana yang ramai, penerangan yang berlebihan, serta kurangnya kebersihan lingkungan. Salah satu terapi sederhana yang dapat diterapkan yaitu dengan menerapkan perilaku sleep hygiene yang merupakan penerapan terapi non farmakologis yang sangat sederhana dan mudah dilakukan dengan modifikasi perilaku dan lingkungan untuk meningkatkan kualitas tidur seperti dengan melakukan olahraga sebelum tidur, mengatur pencahayaan, menghindari konsumsi kafein. Tujuan: untuk mengetahui hubungan perilaku sleep hygiene dengan kualitas tidur pada lansia di Panti Tresna Werdha Ina Kaka Kota Ambon. Metode: Jenis penelitian observasional analitik dengan desain cross sectional study. Sampel dipilih dengan cara non-probability dengan pendekatan teknik total sampling dengan jumlah responden 35 lansia. Instrumen penelitian untuk mengukur perilaku sleep hygiene menggunakan Sleep Hygiene Index (SHI) dan untuk mengukur kualitas tidur menggunakan Pittsburgh Sleep Quality Index (PSQI). Hasil: uji statistik yang digunakan pada penelitian ini yaitu menggunakan uji statistic Pearson chi-square tetapi ada 7 sel $(77,8 \%)$ yang nilai expected count $<5$, maka digunakan uji alternatif kolmogorov smirnov. Hasil uji analisis data menggunakan Kolmogorov Smirnov diperoleh nilai $\mathrm{p}=0,000$ dengan nilai $\alpha=$ 0,05 . Bahwa nilai $p<\alpha$, artinya ada hubungan antara perilaku sleep hygiene dengan kualitas tidur pada lansia di Panti Tresna Werdha Ina Kaka Ambon. Kesimpulan: Perilaku sleep hygiene perlu dilakukan untuk mendapatkan kualitas tidur yang baik. sebab perilaku sleep hygiene dapat memperbaiki kualitas tidur lansia.
\end{abstract}

This is an open access article under the $\underline{C C B Y-S A}$ license.

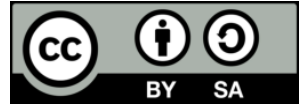

\section{Corresponding Author:}

Fitriyanti Patarru',

Program Studi Ilmu Keperawatan, Sekolah Tinggi Ilmu Kesehatan Stella Maris Makassar,

Jl Maipa No 19, Makassar, Indonesia.

Email: patarrufitriyanti@yahoo.com / Phone: 085341582184

\section{PENDAHULUAN}

Seiring berjalannya waktu perubahan secara fisik, psikologis, kognitif, dan sosial secara alamiah akan dialami oleh setiap manusia. Kondisi ini akan berdampak pada masalah kesehatan seperti gangguan intelektual, gangguan panca indera, depresi dan gangguan tidur. Pada usia lansia akan mengalami perubahan durasi tidur. Lanjut usia merupakan bagian dari proses tumbuh kembang manusia dimana pada dirinya mengalami perubahan tubuh, mental ataupun kesehatan yang saling berkaitan, kondisi ini dapat menimbulkan masalah kesehatan secara fisik dan mental (Ii and Lansia,2016).

Menurut WHO dalam Savitri (2020), didapatkan data terkait jumlah lansia di Asia Tenggara yaitu $8 \%$ atau 142 juta jiwa. Di Indonesia berdasarkan data badan pusat statistik pada tahun 2014 jumlah lansia di Indonesia yaitu 13.729 .992 jiwa $(8,5 \%)$ dan mengalami peningkatan menjadi $10,0 \%$ pada tahun 2020 . Salah satu aspek dalam meningkatkan kesehatan lansia adalah perilaku tidur. Konsep lansia ini mengacu pada penuaan aktif yang sehat secara jasmani, sosial, maupun mental (Annisa, Nurviyandari, and Wati 2019). 
Perilaku sleep hygiene adalah salah satu tindakan maupun upaya dalam bentuk latihan perilaku yang dapat dilakukan seseorang dengan tujuan untuk mengetahui bagaimana cara menciptakan lingkungan yang nyaman di sekitar tempat tidur agar bisa mendapatkan tidur yang nyaman dan dapat memperbaiki kualitas tidur dari yang buruk menjadi lebih baik. Tidur sangat berperan untuk menstabilkan tubuh kembali normal. Pada saat menjadi tua lansia perlu untuk menjaga pola tidurnya karena jika tidur lansia berkurang maka akan berpengaruh terhadap kesehatannya. Lingkungan merupakan salah satu faktor yang dapat mempengaruhi kualitas tidur lansia. Masalah tidur sering terjadi pada lansia yang ditandai dengan perasaan kurang nyaman dan segar ketika bangun, kesulitan untuk memulai tidur, tidak dapat menjaga tidurnya, serta bangun terlalu dini (Amalia,2017).

Waktu tidur rapid eye movement pada lansia lebih pendek dan terjadi perubahan pada keadaan yang dialami sekarang. Adapun gangguan tidur yang ditandai dengan beberapa gejala diantaranya yaitu kesulitan untuk tidur, tidak mampu menjaga tidur dengan nyaman, bangun terlalu dini, dan mengantuk berlebih pada siang hari, sehingga menyebabkan sebagian besar lansia selalu mengalami kualitas tidur yang buruk dan mengakibatkan sebagian besar lansia merasakan ketidakpuasan (Jet al., 2020). Berbagai macam penelitian yang membahas tentang mengatasi kualitas tidur pada lansia yaitu dengan cara mengedukasi terapi perilaku, yaitu dengan terapi sleep hygiene dimana ini merupakan tindakan non farmakologi yang dilakukan untuk memperbaiki kualitas tidur pada lansia, dimana jika perilaku sleep hygiene dilakukan dengan rutin dapat mengubah kebiasaan tidur menjadi lebih baik. Perilaku Sleep hygiene dapat dilakukan dengan cara membuat jadwal dan rutinitas untuk tidur, menciptakan lingkungan yang nyaman untuk tidur, menghindari makanan yang dapat mengganggu tidur, dan menghindari obat tidur.

Menurut penelitian yang dilakukan oleh (Kunci, 2017) di panti Werdha Harapan Ibu Ngalian Semarang dengan judul hubungan sleep hygiene dengan kualitas tidur pada lansia, terdapat responden dengan perilaku buruk berjumlah $26(74,3 \%)$ lansia, sedangkan perilaku baik berjumlah 9 (25,7\%) lansia. Ada beberapa aspek yang dapat menyebabkan perilaku sleep hygiene buruk yaitu karena kurangnya wawasan para lansia, seperti lansia yang menggunakan tempat tidur untuk menonton TV, kebiasaan makan yang tidak tepat, agenda olahraga yang tidak dilaksanakan, dan yang sering mengkonsumsi minuman kafein pada malam hari. Kualitas tidur yang buruk ditimbulkan oleh perilaku yang kurang sehat serta rutinitas tidur yang salah. Dari hasil penelitian yang telah dilakukan didapatkan adanya hubungan antara perilaku sleep hygiene dengan kualitas tidur pada lansia.

Dari hasil observasi dan wawancara dengan beberapa lansia di panti Tresna Werdha Ina Kaka Ambon didapatkan hasil bahwa seluruh lansia mengalami gangguan tidur karena faktor lingkungan yang ribut, sebagian lansia juga mengatakan jika terkadang mereka sering terbangun saat tidur pada malam hari. Ada pula lansia yang kadang sudah mencoba untuk tidur tetapi tidak dapat memulai untuk tidur dan hanya bolak-balik di tempat tidur saja. Berdasarkan latar belakang yang telah diuraikan diatas maka penulis memiliki ketertarikan untuk melakukan penelitian dengan judul hubungan perilaku sleep hygiene dengan kualitas tidur pada kelompok lansia di Panti Tresna Werdha Ina Kaka Ambon.

\section{METODE PENELITIAN}

Penelitian ini merupakan penelitian non eksperimental jenis observasional analitik. Rancangan penelitian ini menggunakan cross sectional study yaitu penelitian yang menekankan waktu pengukuran/observasi data terkait hubungan perilaku sleep hygiene dengan kualitas tidur pada lansia di Panti Tresna Werdha Ina Kaka Ambon yang dilakukan pada waktu yang bersamaan tanggal 06 Februari - 20 Februari 2020. Populasi diambil dari jumlah lansia pada Panti Tresna Werdha Ina Kaka kota Ambon, yang berjumlah 35orang. Sampel dipilih dengan cara Non probability sampling dengan teknik total sampling yang memenuhi kriteria inklusi yaitu seluruh lansia di lokasi penelitian, lansia yang kooperatif dan kriteria eksklusi yaitu lansia yang mendapat terapi obat tidur. Instrumen yang digunakan untuk mengukur perilaku sleep hygiene adalah kuesioner Sleep Hygiene Index (SHI) dan untuk mengukur kualitas tidur digunakan kuesioner Pittsburg Sleep Hygiene Quality Index (PSQI) (Rohmawati, 2018).

Uji statistik yang digunakan pada penelitian ini yaitu menggunakan uji statistic Pearson chi-square tetapi ada 7 sel $(77,8 \%)$ yang nilai expected count $<5$, maka digunakan uji alternatif kolmogorov smirnov. Hasil uji analisis data menggunakan Kolmogorov Smirnov diperoleh nilai $p=0,000$ dengan nilai $\alpha=0,05$. Bahwa nilai $p<\alpha$, artinya ada hubungan antara perilaku sleep hygiene dengan kualitas tidur pada lansia di Panti Tresna Werdha Ina Kaka Ambon. 


\section{HASIL}

\subsection{Karakteristik Responden}

Tabel 1.

Distribusi frekuensi responden berdasarkan usia, Jenis Kelamin dan Pendidikan di Panti Tresna Werdha Ina Kaka Ambon Tahun 2021

\begin{tabular}{ccc}
\hline Usia (tahun) & Frekuensi (f) & Persentase (\%) \\
\hline $60-74$ & 18 & 51,4 \\
$75-90$ & 17 & 48,6 \\
\hline Total & 100,0 & 100,0 \\
\hline Jenis Kelamin & Frekuensi (f) & Presentase(\%) \\
\hline Laki-laki & 16 & 45,7 \\
Perempuan & 19 & 53,3 \\
& & 100,0 \\
\hline Total & 35 & Presentase (\%) \\
\hline Pendidikan & Frekuensi (f) & 62,9 \\
SD & 22 & 2,4 \\
SMP & 11 & 2,9 \\
SMA & 1 & 100,0 \\
Sarjana & 1 & Presentase $(\%)$ \\
\hline Total & 35 & 88,6 \\
\hline Lama di Panti & Frekuensi (f) & 8,6 \\
(Tahun) & & 2,9 \\
\hline $1-4$ & 31 & 100,0 \\
5-8 & 3 & \\
$9-12$ & 1 & \\
\hline Total & 35 &
\end{tabular}

Berdasarkan tabel 1 di atas yang didapatkan dari 35 responden, mayoritas lansia berusia 60-74 tahun berjumlah $18(51,4 \%)$ responden. dengan jenis kelamin mayoritas perempuan sebanyak $19(53,3 \%)$ responden dengan riwayat pendidikan SD sebanyak $22(62,9 \%)$ responden dan lama di panti selama 1-4 tahun sebanyak $31(88,6 \%)$.

\subsection{Analisis univariat}

Tabel 2.

Distribusi Frekuensi Responden Berdasarkan Perilaku sleep hygiene di Panti Tresna Werdha Ina Kaka Ambon Tahun 2021

\begin{tabular}{ccc}
\hline Perilaku Sleep hygiene & Frekuensi (f) & Persentase (\%) \\
\hline Baik & 6 & 17,1 \\
Sedang & 7 & 20,0 \\
Buruk & 22 & 62,9 \\
\hline Total & 35 & 100,0 \\
\hline
\end{tabular}

Berdasarkan tabel 2 didapatkan bahwa mayoritas dengan perilaku sleep hygiene buruk berjumlah 22 $(62,9 \%)$ responden. 
Tabel 3.

Distribusi Frekuensi Responden Berdasarkan Kualitas Tidur Lansia di Panti Tresna Werdha Ina Kaka Ambon Tahun 2021

\begin{tabular}{ccc}
\hline Kualitas Tidur & Frekuensi (f) & Persentase (\%) \\
\hline Baik & 3 & 8,6 \\
Kurang & 5 & 14,3 \\
Sangat Kurang & 27 & 77,1 \\
\hline Total & 35 & 100 \\
\hline
\end{tabular}

Berdasarkan tabel 2 didapatkan hasil bahwa mayoritas dengan kualitas tidur sangat kurang berjumlah $27(77,1 \%)$ responden.

\subsection{Analisis Bivariat}

Tabel 4. Analisis hubungan perilaku sleep hygiene dengan kualitas tidur lansia di Panti Tresna Werdha Ina Kaka Ambon Tahun 2021

\begin{tabular}{|c|c|c|c|c|c|c|c|c|c|}
\hline \multirow{3}{*}{$\begin{array}{c}\text { Perilaku } \\
\text { Sleep Hygiene }\end{array}$} & \multicolumn{6}{|c|}{ Kualitas tidur } & \multirow{2}{*}{\multicolumn{2}{|c|}{ Total }} & \multirow{3}{*}{$p$} \\
\hline & \multicolumn{2}{|c|}{ Baik } & \multicolumn{2}{|c|}{ Kurang } & \multicolumn{2}{|c|}{ Sangat kurang } & & & \\
\hline & $\mathrm{f}$ & $\%$ & $\mathrm{f}$ & $\%$ & $\mathrm{f}$ & $\%$ & $\mathrm{n}$ & $\%$ & \\
\hline Baik & 1 & 16,7 & 3 & 50,0 & 2 & 33,3 & 6 & 100 & \\
\hline Sedang & 1 & 14,3 & 1 & 14,3 & 5 & 71,4 & 7 & 100 & 0.000 \\
\hline Buruk & 1 & 4,5 & 1 & 4,5 & 20 & 90,9 & 22 & 100 & \\
\hline Total & 3 & 8,6 & 5 & 14,3 & 27 & 77,1 & 35 & 100 & \\
\hline
\end{tabular}

Berdasarkan tabel 4. didapatkan hasil bahwa dari 35 responden di Panti Tresna Werdha Ina Kaka Ambon diperoleh data perilaku sleep hygiene baik dengan kualitas tidur baik sebanyak 1 (16,7\%) responden, perilaku sleep hygiene baik dengan kualitas tidur kurang 3 (50,0\%) responden, perilaku sleep hygiene baik dengan kualitas tidur sangat kurang $2(33,3 \%)$, perilaku sleep hygiene sedang dengan kualitas tidur baik 1 $(14,3 \%)$ responden, perilaku sleep hygiene sedang dengan kualitas tidur kurang $1(14,3 \%)$ responden, perilaku sleep hygiene sedang dengan kualitas tidur sangat kurang $5(71,4 \%)$ responden, perilaku sleep hygiene buruk dengan kualitas tidur baik 1 (4,5\%), perilaku sleep hygiene buruk dengan kualitas tidur kurang $1(4,5 \%)$ responden, perilaku sleep hygiene buruk dengan kualitas tidur sangat kurang sebanyak 20 (90,9\%) responden.

Analisis data menggunakan uji statistic Pearson chi-square tetapi ada 7 sel $(77,8 \%)$ yang nilai expected count $<5$, maka digunakan uji alternatif kolmogorov smirnov. Hasil uji analisis data menggunakan Kolmogorov Smirnov diperoleh nilai $\mathrm{p}=0,000$ dengan nilai $\alpha=0,05$. Bahwa nilai $p<\alpha$, artinya ada hubungan antara perilaku sleep hygiene dengan kualitas tidur pada lansia di Panti Tresna Werdha Ina Kaka Ambon.

\section{DISKUSI}

Berdasarkan hasil penelitian yang dilakukan di Panti Tresna Werdha Ina Kaka kota Ambon kepada 35 responden dengan menggunakan uji uji alternatif kolmogorov smirnov tabel 3x3 dengan tingkat kemaknaan $\alpha=5 \%$ atau 0,05 didapatkan hasil nilai $\mathrm{p}=0,000$ dengan nilai $\alpha=0,05$. Bahwa nilai $p<\alpha$, artinya ada hubungan perilaku sleep hygiene dengan kualitas tidur pada kelompok lansia di Panti Tresna Werdha Ina Kaka kota Ambon.

Hasil penelitian didapatkan bahwa mayoritas lansia memiliki perilaku sleep hygiene buruk dengan kualitas tidur sangat kurang sebanyak 20 (90,9\%) kondisi ini disebabkan oleh lingkungan dan kebiasaan lansia yang jarang tidur siang, jarang berolahraga, kebisingan sekitar, dan sebagian dari mereka mengatakan memiliki perasaan cemas dengan berbagai alasan seperti tidak betah di panti dan memikirkan keluarga mereka, serta temperatur ruangan yang tidak stabil membuat lansia merasa gerah dan kedinginan sehingga membuat lansia memiliki perasaan tidak nyaman ketika tidur, kemudian pencahayaan yang tidak tepat menyebabkan lansia kesulitan untuk memulai tidurnya. Ada juga beberapa lansia yang punya kebiasaan sebelum tidur menonton televisi hingga larut malam, dan suka minum kopi, sehingga lansia terbiasa memulai tidurnya pada pukul 23:00 dan 24:00, dan selalu terbangun sekitar 2 sampai 3 kali pada malam hari karena ingin berkemih dan tiba-tiba 
terbangun karena perasaan tidak nyaman. Hal tersebut menyebabkan durasi tidur pada lansia hanya sekitar 4 jam.

Berdasarkan hasil penelitian didapatkan bahwa ada juga lansia yang memiliki perilaku sleep hygiene baik dengan kualitas tidur sangat kurang sebanyak $2(33,3 \%)$. Hal ini dipengaruhi oleh gaya hidup, dimana aktivitas dan waktu kerja yang tidak sama seperti kesehariannya sering membuat lansia kesulitan untuk tidur, karena membutuhkan waktu untuk menyesuaikan diri terhadap keadaan dan kebiasaan di panti. Lansia mengatakan ketika masuk panti mereka membutuhkan waktu untuk menyesuaikan diri dengan suasana panti dimana aktivitas sebelumnya mereka memiliki kesibukan bekerja di kantoran, namun setelah pensiun dan masuk ke panti tentu mereka memiliki kebiasaan yang berbeda dari sebelumnya. Hasil penelitian sejalan dengan penelitian yang dilakukan oleh Kunci,s(2017), di Panti Werdha Harapan Ibu Ngalian tentang "hubungan antara perilaku sleep hygiene dengan kualitas tidur lansia" didapatkan hasil bahwa dari 35 lansia yang mempunyai perilaku sleep hygiene buruk dengan kualitas tidur buruk sebanyak 26 (100\%), dan yang mempunyai perilaku sleep hygiene baik dengan kualitas tidur buruk sebanyak $5(55,5 \%)$, sehingga ada kecenderungan semakin tidak baik praktik sleep hygiene semakin buruk kualitas tidur lansia.

Berdasarkan hasil penelitian maka peneliti berasumsi agar lansia perlu menerapkan perilaku sleep hygiene karena ketika perilaku sleep hygiene buruk maka kualitas tidur lansia akan buruk. Kualitas tidur yang buruk pada lansia di Panti Tresna Werdha Ina Kaka kota Ambon dikarenakan tidak memperhatikan perilaku sleep hygiene yang seharusnya mereka lakukan, sehingga tanpa disadari hal-hal yang dianggap biasa justru menjadi kebiasaan yang membuat kualitas memburuk. Sehingga untuk mendapatkan kualitas tidur yang baik tidak harus minum obat-obatan atau terapi medis, namun kualitas tidur lansia dapat diperbaiki dengan menerapkan perilaku sleep hygiene yang baik.

Pengaturan tidur dan terbangun diatur oleh batang otak (Reticular Activating System dan Bulbar Synchronizing Region), thalamus dan berbagai hormon yang diproduksi oleh hypothalamus. Serotonin merupakan neurotransmitter yang bertanggung jawab terhadap transfer impuls-impuls saraf ke otak yang berperan dalam menginduksi rasa kantuk, juga sebagai modulator kapasitas kerja otak. Dalam tubuh serotonin diubah menjadi melatonin. Pada lansia hormon melatonin ini akan menurun seiring dengan bertambahnya usia, jumlah produksi hormon melatonin dapat ditingkatkan dengan melakukan aktivitas yang dapat memperlancar aliran darah. Terganggunya kinerja melatonin dalam tubuh bisa disebabkan oleh berbagai hal termasuk radiasi elektrik, pencahayaan sehingga hal ini yang dapat membuat lansia kesulitan untuk tidur. Jumlah produksi hormon melatonin dapat ditingkatkan dengan melakukan aktivitas yang dapat memperlancar aliran darah seperti olahraga (Ambarwati, 2017).

Kualitas tidur yang baik merupakan keadaan dimana seseorang bisa mendapatkan kebugaran, kesegaran, dan kepuasan pada saat terbangun. Kualitas tidur pada lansia dikatakan baik apabila tidur malam terpenuhi selama 6 jam, dan waktu yang dibutuhkan untuk tertidur tidak lebih dari 30 menit, serta tidak terbangun lebih dari 2 kali pada malam hari. Penurunan kualitas tidur dapat dipengaruhi oleh faktor lingkungan seperti pencahayaan yang kurang tepat, temperatur ruangan yang tidak stabil, dan adanya suara bising (Khotimah, 2018).

\section{KESIMPULAN}

Hasil Penelitian ini menunjukkan bahwa terdapat hubungan antara perilaku sleep hygiene dengan kualitas tidur pada kelompok lansia di Panti Tresna Werdha Ina Kaka kota Ambon. Perilaku sleep hygiene perlu dilakukan untuk mendapatkan kualitas tidur yang baik sebab perilaku sleep hygiene dapat memperbaiki kualitas tidur lansia.

\section{REFERENSI}

Amalia, Intan Nurfa. 2017. Hubungan Antara Kualitas Tidur Dengan Kelelahan Fisik Lansia.

Ambarwati, Rini. 2017. "Sleep, Circadian Rhythms, and Metabolism." Sleep, Circadian Rhythms, and Metabolism X(1):42-46. doi: 10.1201/b17253.

Annisa, Mutia, Dwi Nurviyandari, and Kusuma Wati. 2019. “The Relationship between Sleep Hygiene and Sleep Quality among Residents of an Elderly Care Institution in DKI Jakarta." 4:89-97.

Ii, B. A. B., and A. Lansia. 2016. "Yaitu Antara Usia 60 - 74 Tahun b. Lansia Tua (." 6-22.

J, Harsismanto, Juli Andri, Tirta Dwi Payana, Muhammad Bagus Andrianto, and Andry Sartika. 2020. "Kualitas Tidur Berhubungan Dengan Perubahan Tekanan Darah Pada Lansia.” Jurnal Kesmas Asclepius (JKA) 2(1):1-11.

Malinda, A. P. (2019). Penerapan relaksasi otot progresif terhadap kualitas tidur pada lansia di panti wredha dharma bhakti pajang laweyan surakarta.

Monica, O., Madi, A., \& Toban, R. C. (2019). Program studi sarjana keperawatan dan ners sekolah tinggi ilmu kesehatan stella maris makassar 2019.

Muhith Dan Siyoto. (2016). Pendidikan Keperawatan Gerontik (edisi 1). 
Munardi. (2017). Faktor Yang Mempengaruhi Kebutuhan Tidur Pada pasien Dengan Perubahan Fungsi Pernapasan. 2(62).

Ni Made Putri Suastari, Pande Nyoman Bayu Tirtayasa, I Gusti Putu Suka Aryana, R. T. K. (2014). Hubungan antara Sikap Sleep Hygiene dengan Derajat Insomnia pada Lansia di Poliklinik Geriatri RSUP Sanglah. Program Studi Pendidikan Dokter Fakultas Kedokteran Universitas Udayana, 2-14

Savitri, Restiani. (2020). "Insomnia Pada Lansia Di Posyandu Lansia Kelurahan Mojosongo Program Studi Keperawatan Program Sarjana Fakultas Ilmu Kesehatan.” 